University of South Florida

DIGITAL COMMONS

Digital Commons @ University of

@ UNIVERSITY OF SOUTH FLORIDA

South Florida

Educational Leadership and Policy Studies Faculty Publications

2008

\title{
Who are Latino/a Prospective Teachers and What do They Bring to U.S. Schools?
}

\author{
Mary L. Gomez \\ University of Wisconsin - Madison, gomez@education.wisc.edu \\ Terri L. Rodriguez \\ University of Wisconsin-Madison \\ Vonzell Agosto \\ University of Wisconsin-Madison, vagosto@usf.edu
}

Follow this and additional works at: https://digitalcommons.usf.edu/els_facpub

Part of the Curriculum and Instruction Commons, Curriculum and Social Inquiry Commons,

Educational Administration and Supervision Commons, Education Policy Commons, Race, Ethnicity and

Post-Colonial Studies Commons, and the Teacher Education and Professional Development Commons

\section{Scholar Commons Citation}

Gomez, Mary L.; Rodriguez, Terri L.; and Agosto, Vonzell, "Who are Latino/a Prospective Teachers and What do They Bring to U.S. Schools?" (2008). Educational Leadership and Policy Studies Faculty

Publications. 4.

https://digitalcommons.usf.edu/els_facpub/4

This Article is brought to you for free and open access by Digital Commons @ University of South Florida. It has been accepted for inclusion in Educational Leadership and Policy Studies Faculty Publications by an authorized administrator of Digital Commons @ University of South Florida. For more information, please contact digitalcommons@usf.edu. 


\section{Rapid \#: -2063378

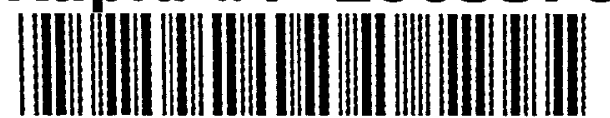
IP: 128.104 .61 .85
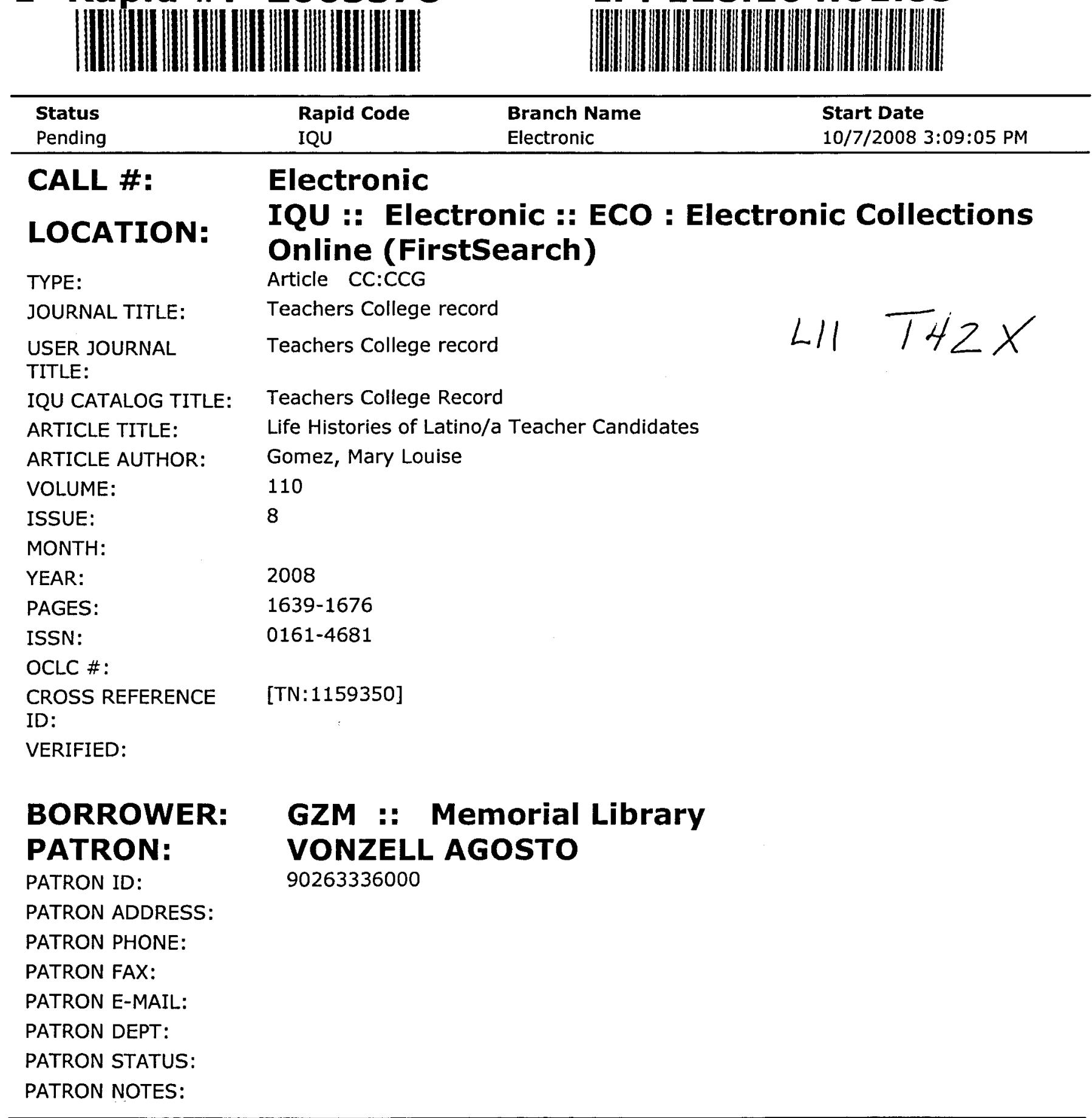


\title{
Life Histories of Latino/a Teacher Candidates
}

\author{
MARY LOUISE GOMEZ \\ TERRI L. RODRIGUEZ \\ VONZELL AGOSTO \\ University of Wisconsin-Madison
}

Background/Context: In this article, we explore the life histories of two Latino/a prospective elementary teachers in a large Midwestern university; examine their knowledge, strengths, and needs as teachers; and consider how teacher educators might capitalize on these. We explore how these prospective teachers' prior family, home, $K-12$ schooling, and university experiences have forged their identities and affected how they think about campus peers and classroom colleagues, and their obligations to their students.

Research Questions: In analyzing these life histories, we ask: What knowledge, strengths, and needs do Latino/a teacher candidates bring to campus when enrolling in teacher education, and how do prospective teachers negotiate these? What implications do Latino/a teacher candidates' experiences have for teacher educators?

Conclusions and Recommendations: Our findings suggest that teacher educators turn their attention to five dimensions of teacher education: whom we hire as teacher educators, how we model classroom pedagogy for students, how we help all prospective teachers excavate their identities, how prospective teachers' language skills and cultural backgrounds are taken into account on campus and in school experiences, and how we deploy experiences with various cultural communities for prospective teachers. Whom we hire as teacher educators is significant because the course content, assignments presented to students, and ways that they take into account the concerns of all students are related to the identity and experiences of the teacher educator. Modeling classroom practices that honor prospective teachers' prior knowledge, experiences, and questions is significant because how they are taught paves the way for what possibilities they see for including all students in their future classrooms. Our analyses also suggest that all teacher candidates require careful reflection on their identities and standpoints, and what these mean for their interactions with and understandings of the viewpoints of peers, colleagues, families, and students. We also encourage teacher education programs to take into account prospective teachers' language and cultural knowledge when

Teachers College Record Volume 110, Number 8, August 2008, pp. 1639-1676

Copyright $\odot$ by Teachers College, Columbia University

0161-4681 
placing students in classrooms and devising assignments for their teaching. Further, we encourage community experiences for all teachers that include interactions with families of different heritage and social class backgrounds so that they might develop more and deeper understandings of various families and communities.

Demographic projections foretell an increasingly diverse student population in the United States in terms of linguistic and cultural affiliations (U.S. Census Bureau, 2000). However, our nation's teachers likely will remain White, middle class, English speaking, heterosexual, and ablebodied, often attending a university 40 miles or less from the small towns in which they grew up (American Association of Colleges for Teacher Education, 1999; U.S. Department of Education, 2001; Zimpher, 1989). One widely discussed remedy for increasing the learning and achievement of a diverse school population is altering the teacher pool so that it mirrors the cultural and ethnic dimensions of schoolchildren and youth. Yet, we pay little attention to how we might craft teacher education programs that respond to the knowledge, strengths, and needs of the teachers of color we are attempting to recruit. To that end, we have been investigating the experiences of prospective teachers who broadly identify as Latino/a and are enrolled in the elementary education program of a large Midwestern research-oriented university, State University. ${ }^{1}$ We asked participants to tell us their life histories via storied accounts of their childhoods and young adulthoods, focused on their family, school, university, and teacher education program experiences as a means of exploring these questions: What knowledge, strengths, and needs do Latino/a teacher candidates bring to campus when enrolling in teacher education, and how do prospective teachers negotiate these? What implications do Latino/a teacher candidates' experiences have for teacher educators?

\section{LITERATURE REVIEW}

Latinos/as constitute only a small part of the teacher candidate and practicing teacher pool (10.5\%; Farber, 1991) in the United States; however, there is increasing concern among teachers and teacher educators, community members, and parents about attracting a teaching force that reflects the cultures and language backgrounds from which students come, and increasing those numbers. Even in parts of the country where Latino/a children and youth constitute a large part of the student poptlation and speak Spanish, their teachers remain largely white and only English speaking. In Texas, for example, Latino/a children constitute 
$40 \%$ of all students (Flores \& Clark, 2005), whereas $75 \%$ of their teachers are White, and in California, $40 \%$ of students also are Latino/a, and $80 \%$ of teachers are White (Yates, 1999). A few scholars have conducted investigations concerning who these teachers are and what challenges and barriers they face on their journey to teacher candidacy. To date, most research conducted about prospective (Clark \& Flores, 2001; Kauchak \& Burbank, 2003; Su, 1997; Tellez, 1999) and practicing Latino/a teachers (Aguilar, MacGillivray, \& Walker, 2000; Galindo, 1996; Galindo, Aragon, \& Underhill, 1996; Galindo \& Olgun, 1996; Monzo \& Rueda, 2001; Valenzuela, 1999; Walker, MacGillivray, \& Aguilar, 2001) has been conducted in the Western or Southwestern portion of the United States, and the teachers researched primarily have identified as Chicano/a, Mexican, or Mexican American. Few such studies of teacher candidates exist, so we also include snapshots of research on in-service teachers and instructional aides in the following discussion. ${ }^{2}$

Studies of Latino/a prospective and practicing teachers and instructional aides highlight a view of families as respected allies with whom they can and should have close, warm relationships. This viewpoint differs from that of many White teachers, who see families' knowledge as "inherently biased to favor individuals" and believe that teachers' "needs to make objective decisions comes at the cost of separation from clients and a devaluing of the knowledge of families" (Graue, 2005, pp. 177-178). In contrast, Latino/a teachers appear not to see families as "inherently biased" about their individual children but as having complex and rich knowledge about their children from which they, as teachers, can benefit. Latino/a educators often extend themselves to help Latino/a children feel pride and motivation to do well in school through informal contacts in the school setting-offering encouragement and support to students on the playground, before and after class, and in their homes (often in the Spanish language). Building on prior personal experiences of dissonance between their home and school lives, Latino/a educators also make children's and youth's activities outside school a topic of conversation inside school. Next, we review the extant literature on practicing Latino/a teachers, all of which, to date, has been conducted with females.

Galindo and colleagues (Galindo, 1996; Galindo et al., 1996; Galindo \& Olgun, 1996) have conducted a series of investigations into Chicana practicing teachers' role identity and its relation to self-concept. These studies resulted in three findings: (1) that these teachers were strong advocates for Latino/a children's achievement in schools, (2) that they sought bonds with Latino/a children that linked students' out-of-school lives with their classroom interests and activities, and (3) that they worked 
toward communicating with parents and for parent participation in classrooms. These studies found that teachers recalled lessons learned from extended family and communities of which they had been members and drew on these experiences to motivate students and strengthen their achievement.

Aguilar et al. (2000) and Walker et al. (2001) studied the higher education experiences of bilingual, biliterate practicing Latina teachers working in two elementary schools in Southern California. These researchers found that gender, ethnic, and cultural expectations created barriers to these women's higher educational achievements, including conflicts between family obligations and school/studying requirements; between Latino/a friends at school and in their neighborhoods; and between the adoption of academic goals and values, and negation and/or negotiation of those values prized at home. Although these women were successful professionals, they recounted significant costs and barriers to their schooling often not experienced by White middleclass teachers.

Studies also have focused on the role of Latina paraprofessionals or classroom instructional aides. Monzo and Rueda (2001), for instance, researched the practices of 24 Latina paraprofessionals and 8 beginning teachers (with no more than 3 years of teaching experiences) in two large public elementary schools serving a predominantly Latino/a community with many low-income families. For the most part, paraprofessionals' prior lives mirrored those of the students they taught, thus providing them with a rich and complex understanding and empathy for children's experiences. Monzo and Rueda found that paraprofessionals especially were concerned with making links to children's families, home, and language backgrounds, and bringing students' out-of-school lives inside school in informal conversations and caring interactions that supported children's learning. Likewise, practicing teachers were concerned with these features of students' lives but became more focused on children's achievement, mastery of concepts, and general classroom management and organizational issues than on children's out-of-school experiences as
their number of years as teachers increased.

A few studies have focused on the experiences of prospective Latino/a teachers. Su (1997), for example, researched the general profiles and dentialing program at a major public university in California. Included were 58 prospective teachers, 21 of whom were "Hispanics." Su found
that "minority" teacher candidates were more aware than their White
counterparts of "the in counterparts of "the inequalities" (p. 337) experienced by low-income families and people of color, were more likely to hold dimensions of a 
social consciousness and to take responsibility for transforming schools and society, and were more aware of institutionalized means of supporting the status quo of differentiated schooling outcomes, such as tracking. Similarly, Tellez (1999) studied 4 female Mexican American prospective teachers enrolled in the elementary education program at the University of Houston (Texas). He investigated these teacher candidates' purposes for teaching and their general experiences in their teacher education program. In particular, Tellez aimed to understand their experiences with Mexican American children and to see whether they were able to "use their ethnic knowledge in ways that supported learning" (p. 561). He found that although the formal school curriculum allowed little or no space for teaching anything related to Mexican American people, culture, or history, the teacher candidates were effective in using informal opportunities to capitalize on what children knew, were interested in, and successfully could do. Tellez noted that efforts at recruiting students of color into teacher education must be accompanied by support for prospective teachers to explore their ethnicity, and think through what it means for their teaching and for children's learning and achievement.

Clark and Flores (2001) investigated the relationship between the ethnic identity and self-concept of prospective Latina bilingual teachers enrolled in a South Texas university. These researchers asked teachers to specify their ethnic background (as opposed to labeling teachers with a generic description as Latino) because much prior research had not distinguished between, for example, prospective teachers of Mexican descent and those who identified as having Mexican American or Hispanic backgrounds (terms used by Clark and Flores's participants). The study authors hypothesized that teachers who thought about their ethnic identity as central to who they were as people was related to a positive teacher self-concept and to students' classroom success. Yet, they found that a Latina ethnic identity varied with these teacher candidates and was not central to how they thought about themselves. Clark and Flores, like Tellez (1999), suggested that the meanings of one's ethnic identity require attention in teacher education programs and that programs should ensure that teacher candidates can enhance the ethnic identities of their students, attending to students' ideas about themselves as successful learners.

Kauchak and Burbank (2003) conducted case studies of two "minority" female secondary teacher candidates, one of whom was of Mexican heritage. Conducted at the University of Utah over the course of a year, the study found that Carmen Valle, a 23-year-old who self-identified as Chicana, strongly believed that "interpersonal caring and communication" (p. 66) were central to her effective work with students from a 
diverse student population. She drew on her personal knowledge of students for all facets of her teaching, including classroom management. For example, she sought to know why students who were "wild" in class behaved as they did and exhorted other student teachers to do the same, believing that knowing why would lead one to know how to reach students. Consonant with other Latinas whose views and practices are explored in this review of literature, Carmen saw all aspects of classroom life as related to the establishment of personal relationships.

We aim to add to this scant body of literature concerning the education and experiences of prospective Latino/a teachers and to see how their concerns, strengths, hopes, and struggles are negotiated in their program of teacher education, whom they see themselves teaching, and how they imagine working with children and youth.

\section{STUDY CONTEXT}

United States census data (2000) reflect the growing population of Latino/a people in the country: Numbers of Latinos/as increased from 22.4 million in 1990 to 35.3 million in 2000 . This is a $58 \%$ increase compared with an overall growth in the U.S. population of $13 \%$. Further, youth under 18 years of age constitute $35 \%$ of the total population of persons identifying as Latino/a, compared with $25.7 \%$ of the total population of persons in the United States, assuring that Latinos/as will be populating schools in large numbers for years to come (U.S. Department of Commerce, 2002).

Nationally, the following dimensions of schooling distress Latino/a stldents, families, and community members: the continued segregation of this group in inferior schools throughout the United States (Donato, 1997; Suarez-Orozco \& Paez, 2002); the tracking of students and their placement in vocational and nonacademic courses in secondary school that further reduce expectations and opportunities for higher education (Donato, 1997); the overrepresentation of students enrolled in special education and the underrepresentation of students enrolled in programs for the gifted (Valencia, Villareal, \& Salinas, 2002); and reduced opportunities for Latino/a youth to be schooled with high-achieving peers in other racial/ethnic groups (Valencia, 2002). Further cause for concern are studies citing the exclusion of links to Latino/a cultures and local communities by schools and schooling (Olmedo, 2003; Valdes, 1996; Villenas, 2001); biased testing policies, procedures, and content (Reyes, Scribner, \& Scribner, 1999); the exclusion or limited use of the Spanish Valencia, 2002); and the of instruction and assessment (Garcia, 2001; 
knowledgeable and who are bilingual in Spanish and English (Garcia; Walker et al., 2001; Aguilar et al., 2000).

Many of these challenges to the schooling of Latino/a children and youth also exist in Lake City, a community of 250,000 and where State University is located. Although there are a few classrooms in the community where bilingual education is practiced, and a small new two-way bilingual school has opened (begun with kindergarten and adding a grade per year), most Latino/a students are taught and tested in English by teachers who are not knowledgeable about, nor are members of, their communities. In Lake City, there currently are 2,500 Latino/a students enrolled in the public schools from grades K-12 of a total school population of approximately 24,000. Thus, Latino/a children and youth constitute $10 \%$ of the public school population, part of a district that also enrolls 5,000 African Americans and 2,500 Asians. English is the dominant language spoken by students in the public schools in this community, and $10 \%$ of students speak Spanish and 3\% Hmong. Student dropout data show that as the Latino/a population in our community has grown, so too has the rate of dropping out of school. In $2003,9 \%$ of students who dropped out of high school in this city were Latino/a, compared with $2 \%$ of Whites who dropped out in the same year. Nationally, the dropout rate for Latino/a youth is a startling $30 \%$ (U.S. Department of Commerce, 2002). These data further illustrate the need for excellent teachers who reflect in cultures and language the growing population of Latino/a youth in Lake City, the Midwestern part of the country, and the nation.

Over a 2-year period (2004-2006), we have been conducting life history interviews with 14 (10 female and 4 male) prospective teachers who are enrolled in the State University elementary education program. All participants self-identified as Latino/a. These students were 14 of the 805 Latino/a undergraduates enrolled at the university in 2005, composing $3.4 \%$ of a total of approximately 28,000 undergraduates. Despite the small pool of Latino/a students whom we could study on this campus, the experiences of this group can tell us a great deal about who students are and what experiences they have in large Midwestern research-oriented universities that traditionally have been bastions of Whiteness, yet are located in states with growing Latino/a populations.

The elementary education program at State University admits $50 \mathrm{stu}-$ dents per semester, the majority of whom are first-degree-seeking undergraduates working toward earning one of two certifications-early childhood to middle childhood, or middle childhood to early adolescence. Students enroll in courses and engage in four 100-hour-duration practica (divided into 8-week segments of 3 half-days per week) and a 20-weck 
period of student teaching during their program. Elementary education at State University includes 14 faculty members: 10 Whites, 3 African Americans, and 1 Latina. Although faculty members administer various practica and student teaching segments of the program, and teach some courses in it, many course sections are taught by graduate students, and all the day-to day supervision of students enrolled in practica and student teaching is conducted primarily by graduate students. Most graduate students are White, although a few speak Spanish or identify as Latino/a, Puerto Rican, African American, or as coming from international contexts. The cooperating teachers/mentors with whom we collaborate in the public schools are located for the most part in Lake City, where $88 \%$ of teachers and support staff are White and monolingual in English.

\section{METHODOLOGY}

In this report of our findings, we confine ourselves to a discussion of prospective Latino/a teachers' life histories and the implications that their knowledge, strengths, and needs have for teacher educators. However, this project is part of a larger, longitudinal study that investigates Latino/a prospective teachers' perceptions and experiences of what it means to be a successful teacher, and how their teacher educators at the university and in the public schools see them as successful. The larger project includes case studies of prospective teachers whom we are observing over multiple semesters in school classrooms, and interviews.

To begin our research project, we obtained lists of students admitted to the elementary education program who self-identified as Latino/a from the office of academic services in our School of Education. Next, we contacted them by phone and e-mail to determine their interests in project participation. All Latino/a students enrolled in the elementary education program in 2004-2006 were asked for an interview; all contacted agreed to be study participants. The majority of interviews with preservice teachers took place on campus in a quiet conference room, although comfortable. All interviews conducted were of 1-2 hours in duration, audiotaped, and transcribed by the researchers. Transcripts were returned to participants for any deletions or modifications that they
wished to make. These semistructured interviews focused on preservice teachers' life
histories and were designed to help us understand the interplay between
the contexts in which the contexts in which they had lived and were living, past and present
experiences in these contexts, and their interpretations and understand-
ings of these. Cole and ings of these. Cole and Knowles (2001) wrote that 
life history inquiry is about gaining insights into the broader human condition by coming to know and understand the experiences of other humans. It is about understanding a situation, profession, condition, or institution through coming to know how individuals walk, talk, and work within that particular context. It is about understanding the relationship, the complex interaction, between life and context, self, and place. It is about comprehending the complexities of a person's day-to-day decision-making and the ultimate consequences that play out so that insights into the broader collective experience can be achieved. (p. 11)

Further, Linde (1993) wrote that life stories, as she called them, are distinguished by the "evaluative point" that the speaker is making about herself or himself, a "kind of moral communication of what kind of a person this is and what kind of actions these are" as enacted (p. 21). Linde also marked life stories by two other characteristics. One is the "extended reportability" (p. 22) of such stories, or a person's understanding of some event as distinguishing an aspect of his or her life as a "culturally defined landmark event" (p. 23) that bears repeating over time, such as one's marriage, divorce, major illness, religious conversion, or death of a parent, sibling, or child. The other important aspect of life stories is that no one story stands alone. Thus, as people age, such landmark events become related to others in a web of life stories, or as Linde said, "Thus, when any new story is added to the repertoire of the life story, it must be related to the themes of the other stories included in the life story, or at least it must not contradict them" (p. 25). Stories of one's life have a theme or themes that can be distinguished as individuals integrate earlier stories into later ones, or drop out stories that no longer fit with those they currently tell.

Mishler (1999) stated that stories that people tell about their lives are characterized by these dimensions: (1) they are socially situated actions located in an "unfolding scene of talk"; (2) they are identity performances, or the ways that we "express, display, make claims for who we are-in the stories we tell and how we tell them"; and (3) they are negotiated between us and the persons with whom we speak (pp. 19-20). Further, he said that narratives are "fusions of content and form" (p. 20) in which the ways that people tell their stories are as critical to our understandings of them as the content of the story. Capps and Ochs (1995) posited that the paralinguistic features of stories-the tone and intonation of their telling - also are important to attend to because they may call attention to how particular stories function for storytellers. It is to all 
these dimensions of the narratives that preservice teachers told us about their lives that we are attending. We recognize that what they told us was a particular cultural performance, an attempt at an effective presentation of their identity for a specific audience at a particular time and place, and further, that what they told us is as important as how they told us the stories of their lives.

Our analyses of prospective teachers' narratives are both inductive and deductive. Our analyses are inductive in that we first sought reoccurring themes in preservice teachers' ways of talking about themselves, their families, schooling from kindergarten through Grade 12, and schooling experiences at State University. At least two of us agreed on the presence of any theme induced from the narratives. Our analyses also were deductive in that we also searched for themes that we expected might be present in Latino/a teacher candidates' narratives from our reading of the extant literature about prospective and practicing teachers and from personal experiences of growing up Latina. Examples of these include themes of prospective teachers' immigration or their parents' immigration to the United States; of discrimination against themselves or their parents; of learning English, and of close family relationships. We also noted prospective teachers' ways of narrating their experiences, and we examined their talk for points of emphasis and ideas about which they seemed especially concerned.

Additionally, after inductive and deductive analyses were completed, we located narratives indicative of an identified theme or themes in the prospective teachers' lengthy life history transcripts, and we named these to highlight the ideas represented in each (J. P. Gee, personal communication, March 2006). These narratives were situated continuous segments of text present in a transcript; in other words, we did not piece these stoeach of which had a beginning mirk events" that participants narrated, sought places in each transcript that were emblematic of notions that had been repeated in varied ways by participants and seemed to showcase how teacher candidates thought about and articulated who they were. For example, in exploring the life history of Sonny Garcia in the pages below, we have labeled two of the stories that he told us--All I had to do was silence myself, you know, like be quiet in the classroom and always say things that everyone else would agree with" and "Get into wrestling, everyone watches wrestling, get into drinking because everyone drinks"-because these seem to be landmark events in Sonny's life story. They show how, when faced with new situations in which others might see him as an outsider in a group, he worked to fit in and become one of the crowd. Each illustrates this theme in Sonny's life story. 


\section{LIFE HISTORIES}

This article features life histories told by two prospective teachers who self-identified, when questioned, as Guatemalan American and Latina. We chose to tell these prospective teachers' life histories because they are representative of Latino/a preservice teachers whom we interviewed. Both were successful university students with grade points of B or above, bilingual in Spanish and English, acting for social justice in the larger university community, and marginalized in their social interactions with their White peers in schools, on campus, and/or in the teacher education program. The first of these accounts is told by Sonny Garcia, who was nearly 24 years old at the time of our interview and was about to enter his final semester of student teaching at State University.

\section{SONNY GARCIA}

Sonny Garcia's parents immigrated to the United States from Guatemala prior to his birth and lived, until Sonny was 13, in an upper-middle-class, and for the most part Jewish, suburb of a large Midwestern city. Sonny is a fluent Spanish speaker and recalls always speaking Spanish and English at home (although today he converses solely in Spanish with his father). Sonny was one of three siblings whose parents worked between two and three part- and full-time jobs throughout his childhood as a means of maintaining their residence in this upper-middle-class context. Sonny's mother had lived in the United States since she was 16 years old, having immigrated to this country with her father. She was an ambitious and successful entrepreneur all her life, selling various manufactured products in direct home sales in the urban area where they lived. Later, she did the same in Guatemala, building successful businesses. As a child, Sonny often went on sales calls and deliveries with his mother and had a chance to see how families in different social class groups lived. He reflected on how these trips allowed him to see the living conditions of wealthy people and those who had very few material goods. Of the latter, he said, "You know, seeing families living in apartments, kids with not so many toys or clothing, or [families] with no cars, just the quality of living varied so much throughout different families." Sonny indicated that seeing how other people lived-some without toys or clothes or their own transportation-made Sonny feel fortunate despite his parents' absences from home due to multiple jobs and long work hours.

Sonny never told us specifically how his father was employed, but be did say that his father did not continue his education once in the United States, and often he was bone-tired from hard physical labor. Sonny had 
stopped asking his father for money once enrolled in the university, and he worked four jobs in one semester when we spoke to him. He was employed at a campus pizza restaurant, was a paid tutor for middleschool students of color in a campus program aimed at preparing them for college, worked in sexual assault prevention for a university group, and worked in helping other college students with their academic projects in a university computer laboratory. Sonny is industrious and determined to pay his own way in school, not troubling his family for funds.

Sonny characterized his childhood and early adolescence as one defined by caretaking his younger brother and sister. Because his parents worked at juggling several jobs and raising their children, he said,

From age 6 to 13, I was babysitting my little brother and sister; I was in charge of the house-I was in charge of making sure they had their lunch ready for school and when we came back from school; I was in charge of making sure everything was cleaned up after we watched TV and did our homework.

As Sonny grew older, his skills at caring for, mentoring, and tutoring his younger cousins and his brother in particular, were observed by his extended family, many of whom told him he would make an excellent teacher. As an adolescent, Sonny began thinking about the possibility of
becoming a teacher.

Sonny's family frequently returned to Guatemala in the summers when he was a child and preteen, and while there, he honed his teaching skills, working with several cousins and neighborhood children whose parents wanted them to learn English. At age 13, his family returned to Guatemala to live full time, and over the course of that year, his parents decided to divorce. Sonny's mother and younger sister stayed in Guatemala while he and his brother returned to their U.S. hometown with their father. After this yearlong absence from his former school and classmates, Sonny noticed a big change in the ways that he was regarded in the community. His new high school enrolled students coming from several junior highs, and Sonny noticed that students who had not grown up with him interpreted him differently than his old friends did. Sonny said that these students saw him as a new immigrant who might be from Mexico, doubted his English language skills, and generally were dismis-
sive of him as a person.

Below we present what Linde (1993) called a "culturally defined landmark event"-a narrative in which Sony explores how he felt upon recognized how students were interpreting him. Sonny described what 
happened as precipitating "a huge identity crisis" for him. Drawing on Sonny's words, we name this narrative to highlight a theme that we identified in his life story: how when Sonny recognized differences between himself and others, he consciously developed strategies to reduce and accommodate those.

"All I had to do was silence myself, like be quiet in the classroom and alway's say' things that everyone else would agree with."

It was an interesting thing to see how they treated me; I was a new kid who had just showed up in the middle of his freshman year. They all assumed I was from Mexico, had little English or little education. The way they talked to me, the way they spoke to me socially, was like you may not be smart enough to talk with me, I don't think I had to prove that to anyone, but maybe eventually I proved myself to everyone around me.

People were like, who is this kid who's a lot more vocal, who's a lot more genuine about who he is, but doesn't meet the standards of [name of suburb]-which is this elite rich community where everyone is too cool to answer the questions or too selfconscious to raise their hand and ask a question about a problem they're having with an assignment and people were thrown off [by me] and I eventually reverted back to what they were doing because I saw I wasn't as accepted as the rest of the people around me. . . I went back really quickly to adjusting my social skills around what they thought was the norm; eventually, I fell right into it.

Part of fitting in at the high school was just like not being as verbal. I mean the school was very self-conscious and people there were like, we're just more quiet-it was like very like preppy, very like I'm too cool to like you. It was just as easy, all I had to do was silence myself, you know, like be quiet in the classroom and always say things that everyone else would agree with. When you're in lunch or in free time you know there will be approval, so that was really easy-it was mind-numbing you know.

My counselor threw me in all level 3 (the lowest level academic classes) because without looking at my portfolio or file, he assumed I was from another country with little English skills and little education. He threw me in ESL courses. I was getting As in 
algebra because I had already taken algebra. It really made no sense. When I took geometry my sophomore year, I moved to level 2. I moved up by showing that I had the grades to do it. You just needed to take the time to look at me and see, oh, he grew up here. My whole life is here [voice rises and words are emphasized].

Sonny's strategy to assume a nonchalant, "cool" student posture in class and to mirror other students' behaviors paid off socially as his White peers became more accepting of him. However, he found that although students were more welcoming, counselors and teachers did not see him as one of the elite and failed to have high expectations for him. However, he worked hard and moved up a level in his courses while accommodating to the social norms accepted by his wealthy suburban peers. Sonny's rising intonation and strong emphasis on the final words of this narrative show that, despite others' interpretations to the contrary, he was determined to belong.

When his senior year came, Sonny visited college campuses with a classmate and the classmate's mother, as Sonny's father, although agreeing that Sonny should go to college, "did not have a clue" how to help his son achieve that aim. Sonny said,

I didn't really have anyone like my parents to tell me, like, you should do this or you should do that. It was just kind of following the other fish in the river, you know, following through with what they [other students] were doing. So, when it came time to apply to colleges, you know, I said I am applying to State.

Sonny chose State University with the help of a Latino high school guidance counselor who had completed his master's degree at State and urged Sonny to attend a high school summer program for students of going to the campus. He said of his decision to attend State, "I said I am other schools where because it's the closest [to his home compared with because I had gone he had applied], and I was familiar with the school went to [another to the summer program there. My whole high school Once enrolled, state university]." when he returned from found himself in a circumstance similar to that color on a primarily Whatemala: Once again, he was a new student of how he used strategies campus. In the following story, Sonny narrates school when he argies reminiscent of those he had developed in high "social and political at State-that despite being more interested in 
other male students on campus enjoyed as means of fitting in. We see this story too as a "culturally defined landmark event" because it is linked in theme to Sonny's earlier accommodation to high school students' behaviors; he did not want the earlier interpretation of him as someone different to become prominent in his new social life on campus.

\section{"Get into wrestling, everyone watches wrestling, get into drinking because everyone drinks."}

I think more than anything, my biggest realization that I was different from everyone else because I think even still like being in [my home community] and knowing a big group of people from [there] with my peers, I never felt like I was being treated differently or seen differently once I started fitting back into the norms of the school, but once I got to college, I definitely saw it was a different response [to me], a different treatment as a person of color and that was here at State, I mean here in the dorms, realizing that people were not as welcoming to me. I think it was, it wasn't that people were racist, I think it was just people weren't sure if they were going to get along with me because they thought I was completely different from them.

Coming here it was like get into wrestling; everyone watches here at State; get into drinking because everyone drinks, you know, before the football games on Friday and Saturday. I played the video games that people did on my floor and played sports outside the dorms, and I mean some of those things I already did on my own before going to college, but I didn't watch wrestling anymore. That was something I did when I was 8 . Then, I just stopped and I didn't realize it was such a big culture among grown-ups you know, and 18-year-olds. So then, I got back into that, but I never really got genuine about it. It was kind of something to fit in socially. [Sonny talks briefly about being an out-ofstate student at the university and how it might mean you were smarter because it was harder to "get in," but it also might mean you needed more financial aid. He then returns to notions of what people talk about on campus.] .... On a social level, sometimes I am more oriented in academic talk, in talking about social issues and the people I was around in the dorms and stuff, I felt like they wanted to keep academics in the classroom and they wanted to keep football and wrestling in the conversation when they weren't in class. Those are fine for me to talk about 
every now and then, but I would have much rather talked about something else.

While working to be accepted in the dorms, Sonny also began to seek out people who had similar interests to his own. For example, he sought organizations that were conducting activist work on campus. Although he said that he "was never an engineering major," he volunteered for the Society of Hispanic Professional Engineers, helping with "advertising and outreach and chalking up and postering up their events." Sonny also was active in sexual assault prevention on campus, joining an organization that focused on changing male behaviors toward women. Additionally, he self-financed two alternative spring break work trips-one to New Orleans and another to California, both of which were focused on tutoring and education for low-income children of color.

Tragically, Sonny's mother and sister died in Guatemala when he was 21, and Sonny left State University to return there and manage his mother's businesses for many months. With the encouragement and support of a faculty member, Sonny reenrolled at State, and although he continues to travel to Guatemala twice a year, he now is completing his teacher education program. It is Sonny's goal to teach kindergarten or first graders in a bilingual classroom. He said,

I would like to teach little Latino/a students English and Spanish at the same time about anything and everything because I think the majority of times Latino/a students are coming from experiences in life that aren't as ideal or traditional. You know, a lot of the students that I work with in the White classrooms have their family, you know most of them are together; they haven't had to move in their lifetime. They haven't had to deal with issues of language or culture and those are the kind of things Latino/a students deal with-how they're viewed in a grocery store or in a library or on a sidewalk or on a playground and is it okay or is it not okay for them to talk in Spanish in public. There are questions of identity and issues of identity that White kids aren't really dealing with, at least in my opinion [He talks about his own challenges with these issues-what he calls "identity crises" at ages 13 and 18.] ... Those are the kind of things that I would love to approach students and teach them, "Listen, it's okay for you to talk in Spanish and whatever you want, and it's okay for you to be Latino/a when you want and when you want to be American when you want or all of the above. No one has any right to judge you and tell you who you need to be and who you should be." [I 
want to] give them confidence in themselves because a lot of times another teacher would overlook that.

Given these goals, Sonny most appreciated that he sought and was placed with teachers who spoke Spanish or were Latino/a (two of the three teachers he was placed with were Latino/a). He said of his favorite experience,

I worked with Lucia Sanchez at Lacey School in a bilingual K-1 classroom and they were all primarily Mexican. It was my first time in a formal environment with-I was there as a practicum student, you know, teaching and working with someone who was Mexican American. This teacher I felt more connected with. I felt like I could talk to her about anything, not just school, but my life, her experiences in education and in teaching and it was so awesome being able to speak in Spanish to students, to little 5and 6-year olds and switching off from English to Spanish and teaching them how to read and write in English and Spanish.

Sonny also spoke of how he asked lots of questions of the children about their lives, their families, and their experiences with the intention of showing his interest, approval, and understanding. He said of this practicum, "I loved it, I mean I loved it, I mean I loved it and I think the kids loved it." His repetition and emphatic statements communicate his great enjoyment of and comfort with children who reflected his Latino/a background and experiences.

This context contrasts sharply with another placement in Barnes Road School that Sonny described as primarily populated by White students and teachers. He said,

I have no problem with all White students or an upper-middleclass community, but what I guess I do have a problem with is the formal expectations and the superficiality that exists in those kinds of institutions. Just eating lunch in the teacher's lounge was very superficial. It was like "Oh, how are you? I am fine. Oh, great to hear about that, you know." They seemed very fake. It seemed very superficial the way teachers talked to each other, but being in the classroom with my teacher and spending lunch in the classroom, it just felt very free and open and we could talk about anything. It could have been I had more to relate to with her. We talked about issues of identity and issues of language and culture and our own families. There was more of a connection 
there. It could be that, too. I never felt like I had to be silenced to meet the expectations of professionals and the staff.

At Barnes Road, Sonny also told of his cooperating teacher taunting him on a day when he wore a sweatshirt and casual pants rather than the sweater and dress slacks he often wore. He heard her first speak to his peer practicum partner and say, "Sonny is not dressed too formally today." Later, she approached Sonny and expressed the same sentiment and subsequently also spoke to his university supervisor about his clothing (who defended Sonny as always appropriately dressed when she had come to the school). Sonny told us that he had been ill on the day in question and was aiming for warmth rather than style in his attire. He felt that the teacher was angry with him about a day earlier in the practicum when he had not gone on a field trip with the class; he had asked his peer practicum partner to tell the teacher. Sonny recognized that he should have told the teacher himself that he would not be accompanying the class on the outing, but he felt that rather than confront him about the missed trip, the teacher chose to criticize his apparel. For Sonny, these Conversations represented another instance of the superficiality of some when you were, who might either be kind to your face and criticize you quential because they were concerned you on something inconsewhich they would were concerned about something else-about teachers countered these with To date, his experiences with Latino/a What othere with Whites.

tion? Primarily, these refoncerns did Sonny have with his teacher educaof his peers conductinglved around two issues. One was that he saw few cerned the multicultural the readings for courses, and the other conhe said he personally had content of the program. Of the course readings, semesters because the univead less and less as he had moved through the dent discussion. He felt that eity teaching staff left few openings for studidates accountable fort that either his teachers should make teacher canfewer reading assignments. (as a man of color) for atse also worried that he might be singled out although he did not offer instion for not doing the required reading, expressed worries about instances when this had occurred. However, he frequently the lone man the potential for this happening because he was cerned about the multiculu color in his classes. Further, Sonny was con-

content of his courses, saying,

They beat it over our heads, multiculturalism. I think it's importion ... but the growing diversity of schools and the popula- 
mine was that what we're being taught now was something people have studied thoroughly, and it was approved and found important enough to be taught to us as future educators and it's already outdated, it's like 5 years old and it may still be applicable, it may. . . I kind of worry, who's the one deciding what's important and what's not important on what we are being taught as educators, and is it all really relevant if we're deciding to go back to schools that don't have any of these issues?

There may be two implications we can draw from these concerns. First, one may rely on one's own experiences when thinking that theories do not apply to them and that Sonny personally had many experiences with feeling different from others and being different from others to draw onunlike his White peers, who were exhorted, through the literature on multicultural education, to try to understand difference. Second, although Sonny had had a wonderful time teaching young Spanishspeaking Latino children, there was a part of him that longed to return home to the suburbs-where he had said he felt like he "belonged": "This sounds really awful, but from the beginning what I've always wanted to do is go back to [names his home community] and teach because there's fewer problems that I'd have to deal with." In addition, Sonny too believes that there might be contexts in which multiculturalism is not needed because few people in these places reflect dimensions of difference from those who are White, reflecting a position counter to that presented in his classes. Later, Sonny said,
Sometimes all I want to do is travel and learn languages, learn cultures, learn religions, meet other people, and teach other people what I've learned and what I've seen along the way in my life. You know, write books, write kids' books, come up with some school or some program where I can take a class of 15 for 6 months and travel around the world with them, and if parents would let me do it, and be that kind of teacher, because I just think that teaching is just so much more formal than I ever imagined.

These are among many conflicts that Sonny must negotiate as he becomes a classroom teacher-for example, those of wanting to feel accepted by White peers and accommodating to their ways of behaving, versus feeling ethnic pride and strength as an individual. In addition, he must negotiate wanting to teach young Latino/a children whose growingup experiences mirror his own while longing either to return to his home 
community, where his life had for a time been less stressed by selfreliance, or to do what he felt his teacher education program honored, working in what he called an "underprivileged school." Further, Sonny must resolve, in some fashion, the tensions that he feels between the formality of classroom life and what he sees as the easygoing relationships that he had found with Ms. Sanchez at Lacey School.

\section{PATRICIA MORALES}

Like Sonny Garcia, Patricia Morales's parents are immigrants to the United States; her mother is Costa Rican and her father is Venezuelan. Patricia's parents met when they were university students in Costa Rica and, according to Patricia, her father convinced her mother to marry when he was offered a full scholarship to study for a doctorate at the University of Florida. While there, her mother gave birth to three children: two sons and Patricia. Subsequently, her family moved eight times as her father sought increases in corporate rank and salary, including a long stretch of years in Venezuela after he completed his doctorate. Patricia's mother is a certified special education teacher and has taught different subjects in various areas of the United States. She now teaches secondary Spanish in a high school in a Midwestern state, where Patricia's father works for a large U.S. corporation.

Also like Sonny, Patricia is fully bilingual at age 23. She learned Spanish at home as her first language and also was schooled in Spanish in Venezuela as a grade school student, after which her family moved back to the United States following a political coup. Patricia recounts how challenging it was to speak English continually, and the discrimination that her family met because of their accents: "Well, like you come here, people though you are really from an upper-class, well-educated family, think you must be a matina or they come to learn you are Latina, they based on ethnicity."

This tension betwee

troubled Patricia as it did Sown you see yourself and how others see you her mother's birth into did Sonny. Her vision of who she was-based on ily, and her school classmates' status person with little edes' interpretations of who she was as a lower especially because her father hadion and knowledge-was problematic, university, and her mother was a teacher with numerous certifications.
What Patricia saw as faulty understandings especially troubling because sherstandings of her and her family were pret other people's English she often was called upon as a child to inter- 
and spoke English very well. This alternately embarrassed, frustrated, and infuriated Patricia, who recalled saying to her mother, "I'm just like, she just spoke to you in English you know, why don't you answer her?"

The four stories that we tell next represent themes induced from Patricia's interview transcripts; all are landmarks in her life because they show her consistently to be an outsider. Wherever she goes, who she is becomes open to scrutiny and dismissal. The stories are indicative of ongoing prejudice that Patricia sees circulating in the United States and regard the linguistic and cultural stereotypes that nourish prejudicial behaviors. In the first two cases, these narratives concern prejudice aimed at Patricia's family, and in the third and fourth, she recounts how peers in her teacher education program unconsciously perform racism in their behaviors yet tolerate no critique of these, further marginalizing her from university classroom life. We have titled these stories as follows to showcase their thematic cores: "Once my mother was at [a large discount chain store] and I remember this one just topped them all-I've never seen my Mom so furious in all my life"; "Oh, come on, shut up, you Mexican"; "In my [Laura's] school play I was Harriet Tubman so my mom put shoe polish, black shoe polish all over my face"; and "I always feel like everybody else is blue-colored pencils and I'm the red one." In the first of these, Patricia recalls feeling initially embarrassed and then proud of her mother when there was a misunderstanding in a store and she was accused of trying to cheat the business.

\section{"Once my mother was at [a large discount chain store] and I remember this one just topped them all-I've never seen my Mom so furious in all my life."}

My Mom started seeing this and kind of realizing that just because we speak with an accent doesn't mean we can't understand. It was in stores like at [she names a popular chain store for outerwear clothing]; I remember going there all the time as we were growing and had to get like coats every 2 years. My Mom would ask the clerk, like, "Do you have this in a size 7?" but with an accent, and the clerk would turn to me and be telling her, "We have it in a size 9, or something."

Once, she was at [she names a large discount store], I remember this one just topped them all off-I've never seen my Mom so furious in all my life where she was trembling. Ste was so furious, she went in and she was returning a [jar of] cream, and my Mom brought the wrong receipt and my Mom didn't realize that. And the lady thought she was trying to do something, something 
deceitful. She [my Mom] said, "I just checked it; this is the right receipt, and the. . "-it actually was an African American lady, said, "No, you don't understand." She was being completely rude, and talking louder. Somebody came over as they saw how agitated both of them were with each other. She [the person who came] said, "Let me give it a try, to explain it to her." The other clerk said, "She understands exactly what she's trying to do, to get away with all this." My Mom just dropped the cream on the desk. She's said: "I want to speak to a manager now." Everyone was quiet. She said, "Didn't you hear me? I want to speak to the manager now." Everyone came over and then another lady came over to help and she said, "That is the manager." My Mom right there just lost it; she grabbed the cream and put it back in her bag and started walking out because seriously, my Mom is the classiest lady.

Then, the lady actually chased her down, and my Mom told her, "Just because I speak with an accent doesn't mean I don't understand." My Mom said, "Okay, it's the wrong receipt, but I'm just trying to do a simple return." [Patricia offers more explanations regarding the conversation.] They took the return. I think it was store credit or something; but even when my Mom got home, I remember her trembling, she was so mad, and it's those little things you don't even realize that they do or they say ... [that humiliate people]. It was very hard for my parents because when we left Venezuela [after her father earned his doctoral degree], we were upper class and it was very hard for them to transition with everyone assuming that you, when they hear my Dad was an animal nutritionist, or working in agriculture, and they assume he was a farmer. My Mom's friends say, "You know start calling him Dr. Morales in front of people, tell them to address him as that, and you shouldn't have to listen, she insisted, you shouldn't have
to listen."

The emphatic repetition of these final words in the narrative signifies her mother's unwarranted humiliation: How could people treat her mother like this when she was married to a very educated man? Perhaps they should capitalize on Dr. Morales's degrees and show that they were people to be respected. However, Patricia learned that her father's occlpation and education meant nothing to her classmates in the large rural high school (near a Southern city) that she attended for 2 years. Patricia said that she experienced "racism" there by Black and White peers based 
not on language background but on her skin color. At first, she said, students were impressed that she lived in a large home but then questioned Patricia: Did she actually live in the house or did her mother work there? Classmates speculated that her father might be an illegal drug dealer.

Obviously houses are cheaper in the South than they are in the North, and basically, we had like a mini mansion. We really did, it was a gorgeous brick house you know and there would be people who were driving us home when we started making new friends, they were like wait, you live here? What do your parents do? Does your Mom work here or assuming-you know the whole maid thing, the favorite was, "Oh, so your Dad must be a Colombian drug lord or something!

Classmates at her high school also made a "joke" about her heritage in a psychology class, linking Patricia's ethnicity and skin color to being a "Mexican." At first, Patricia tried to laugh off the rude remark with the other students, trying to deflect what she said others saw as a joke. However, the next day in class, the teacher referenced the students' joking of the prior day, and Patricia saw that the taunting was not going to diminish without her intervention.

\section{“Oh come on, shut up, you Mexican."}

Something happened in class and the basketball coach who was joked around all the time, and I'm the one who initiates it most of the time. However, one of the things that they were making a joke of, and someone said [to me], "Come on, shut up, you Mexican!" And I was just like, "Ha ha." It was kind of like a joke and I was like, "Ha ha! Very funny"-you know you may as well, whatever, laugh. Then the teacher kind of made a little reference to it the next day, and I got a little mad. The coach joked about it sometime during the week-he kind of threw it in there again, and then cause they knew I was very proud of my identity, and to them [the other students], it was you are either Black or White and nothing in between and if you are brown, you are Mexican.

Where I lived in this boonies area, it wasn't very common to sec people with brown skin. Then, it got to the point where everyone, when I would hit them with a zinger, or whatever, they are like, "Shut up, you Mexican." It continued for about 2 more 
weeks and I about had it. I snapped on one of those days, it took for me to snap twice at people in the classroom for the coach to just tell everyone to stop; he said, "I don't want to hear all that mess with the Mexican thing, I know I joked around about it, too, but I don't want to hear that mess any more in this classroom period. If I hear it in the hallways, that is it; I am giving you a detention immediately!" To this day, I'm like, "Why didn't you say any more?" I was very mad because it took so long for him to step in, first of all.

This incident remains a painful memory for Patricia-her teacher failed to protect her; rather, he joined in the racist bantering promulgated by both White and Black students. Patricia wondered if you could count on anyone for support when these incidents occurred; certainly, her mother's experiences showed that you had to handle these incidents yourself.

Patricia's family moved again at the end of her sophomore year of high school, this time to a state bordering that in which State University is located. Although her high school guidance counselor told her "she would never get in" to State because her B-average grades and "20 afterschool activities" would not meet the criteria for admission, Patricia persisted, applying to State and six other schools. She targeted State for the excellent reputation of its elementary education program. After her initial application was wait-listed, she was accepted to the university. However, once on campus and in her teacher education program classes, she, like Sonny, saw that her peers primarily saw differences that distinguished them. This was apparent especially when her cohort group (which moved through the program courses and field experiences together) socialized; Patricia found that she consistently was excluded from social events that the group hosted.

In an effort "to make a place," "to build a community" for herself where she could dance and have Latina friends who accepted her, Patricia
founded the first Latina sorority on campus in 2005 . Active in its governance, and social and cultural activities, she said,

I feel that I've been able to be happier by founding the Latina sorority here and really building a family for myself away from home [be]cause that's been a big part of it for me. I didn't feel like I belonged here; I didn't have somewhere to go dance on weekends where I can just dance with my friends [be]cause everything is about sitting down and drinking you know; I think
I've really found a place for myself. I created a place, I created a 
home and I'm glad that I created a home for future ladies to come here to the university.

Patricia also leads an interest group for the sorority, reading Latina literature-but not all of it written in Spanish because not everyone in the group can read Spanish. She explained, "They're like always feeling like 'I want to make others happy, so they'Il let me into the group' and I don't want that type of feeling for them. You know it's not about them making us happy, it's about them making themselves happy and feeling comfortable."

She explained the antipathy she feels for a number of her classmates, many of whom do not think beyond the surface of people's behaviors. She explains that many prospective teachers also do not want to be questioned about their prejudicial assumptions, and she offered the following example as evidence:

\section{“In my [Laura's] school play I was Harriet Tubman so my mom put shoe polish, black shoe polish all over my face."}

There's a girl in my class, let's call her Laura, and she was telling us about an experience of how she was in a school play. She's like, "I remember in my school play I was Harriet Tubman so my mom put shoe polish, black shoe polish all over my face," and I said, "Do you realize how racist that it is? Do you realize that that goes back to all of this history?" [She said] "It's just like well, it was just a school play." But, I'm thinking, "Holy crap! What impact would that have had if there was a kid or somebody that identified as Black there?"

Another student in the class said, "Oh my god, these girls I worked [with] last summer, I was volunteering, and I thought it was going to be so fulfilling and everything, but it was like the worst time of my life because there were all these Black girls and they talked, they were talking about men and all of this stuff and they're just little girls and they're doing all of these booty dancing things and I'm, oh my God I was just so appalled by it." [I said] "I don't know, you know, what if they come from a different socioeconomic status, first of all, which you're not used to obviously, because you are obviously an upper-class girl, and maybe [you should] think outside the spectrum, maybe think about the kind of music that's available nowadays and the kids are all listening to that type of music and look at the music videos." 
It's just with this particular student, I don't say anything anymore because she says so much stuff like that all the time and we've heard it so much that we've just come to where we just ignore what she says. [Chuckle.] It's very sad [be] cause I don't feel like I can say anything and really make an impact on her anymore. I do feel like this is the most racist girl in our classroom; she is the only racist girl, like outright racist, and its hard for me to be in a classroom where she voices her opinions, and I want sometimes, it just takes me longer to just think about what I want to say without just cussing her out immediately in the classroom, so it's hard [to argue with her.]

Patricia felt herself silenced in these settings in which she heard peers in her cohort group say outrageous things. They did not wish to be questioned by others, nor did they wish to interrogate their own belief systems. Both the peer who had blackened her face for a role in a school play as an African American and the others who made assumptions about
the culture of those with whom she "volunteered" were secure in their convictions. They did not wish to be questioned by Patricia.

Patricia believes that her peers in the elementary education program do not perceive or understand the dilemmas of students who want to do well in school and are struggling to do so. Few of them have had problems in school, and they do not see others' challenges as worthy of their attention. She said,

\section{"I always feel like everybody else is blue-colored pencils and I'm the red
one."}

These kids that are coming in [to the elementary education program] are straight-A students since they were in elementary schools, like all their lives, and they've never really had a challenge with anything; seriously there's been like three out of the 20-something kids in our class like have faced something like one of the students in our class had dyslexia and two of us had ESL. Those are the only problems that I've known of and that's it. I
don't feel like a lot of the students are . . . even though we did
receive the multicultural receive the multicultural education [material]; they just responded to the questions of why we should have multicultural classrooms and stuff like that. They know how to answer the questions, yet they don't implement it. A lot of the stuff that they say, I call them out on it and they get annoyed by me calling them out on it, that it's racist what they're saying, they like the way they 
think, and the way they say it and it's just very infuriating for me because out of the three people that are not White in the classroom Frank, myself, and Stephanie (a Korean girl, um, she was adopted by a White family), I'm the only one that identifies all the time as a student of color. .. I'm the only one that seriously identifies as a student of color and it's hard because my perspective is completely different from everybody else's. I feel like sometimes people just get sick and tired of me challenging their thoughts. I always feel like everybody else is blue-colored pencils and I'm the red one. You know, I kind of feel like that all the time, for me.

It is Patricia's goal to have high expectations for all her students, and "just not settle for, you know, just the least bit from them." She considers how her behaviors will affect the futures of her students; she sees these as linked: [You have to] be organized; I think you should be organized because that really helps the kids' future, the more organized you are the better you are going to do a [your] job for them." She sees many of her peers creating explanations for why they cannot accomplish some of what she and the program aim for; they use their small-town backgrounds as excuses. She quotes them as saying, "I'm from a small town and I never dealt with that situation before." Instead, Patricia posited that her classmates should take on these challenges:

You have the opportunity now, so go and do it. Really go out there and try it. You know what, if you're scared about it or whatever, that's fine. But you gotta go out there and face your fears; shoot, I took entomology class here in college. I'm so damn afraid of bugs and now I'm less afraid of [th] em you know like I can deal with it. So, I think you've always got to challenge yourself and I'm not afraid to do that.

However, she sees her peers as afraid, uninterested, not motivated, and making excuses for why they cannot accomplish the hard work necessary for addressing students' classroom challenges. Patricia feels that this situation in her classes leaves her feeling angry and alone-the only one in her cohort group who identifies "all the time as a student of color" and who asks challenging questions of classmates who say things that demonstrate their ignorance of issues of race and social class. And she dislikes feeling "like [she is] the angry one all the time." She said that she is thinking about moving to Florida after her May 2006 graduation, where she can "be with and teach more Latino people." 


\section{WHAT CAN WE LEARN FROM SONNY'S AND PATRICIA'S LIFE HISTORIES?}

Through telling and analyzing Sonny's and Patricia's life histories, we expand a set of "cases" concerning Latino/a prospective teachers, about whom we currently know little-especially those who live outside of the Southwest or Western United States. Aguirre (2005) wrote, "My personal narrative takes a side in order to show the reader that there are competing perceptions of social life that can instruct us" (p. 151). So, too, do our stories show sides of teacher candidates' experiences through their life histories-their narrations of experiences and interpretations of these experiences. As life histories do, these take a side or propose a narrative thread that connects one experience to another. What sides of Sonny and Patricia do we see in their narratives? Both are bilingual in Spanish and English, as are other students we interviewed; they are very good stusity; each has had significant painful experiences with acceptance and understanding by school and university peers; and both have experiidenced challenges in their teacher education programs regarding their her lifetime Each also experienced significant family challenges in his or and from Guatemala were very diffic mother and sister and his moving to eight moves around were very difficult for him, as was Patricia's family's readjustments acros the United States, and subsequent adjustments and ful young people with strong opinions. Like other college students opinions.

on campus for people who are like them their initial months and years they believe, and what they like to do-Sonny and who they are, what such friends. However, often they had to look further and harder for people who reflected their identities on a primarily White campus in a community that also was primarily White, but with growing numbers of
Latinos/as. Sometimes, these searches led them to craft opportunities for
relationships with likeming relationships with likeminded people when these were not readily available. Patricia's founding of a Latina sorority was motivated by her desire to alleviate the challenges of "fitting in" (that she had experienced) for her sorority sisters. She hoped that her Latina sorority sisters would be proud, independent, and able to speak their minds in a community where they could be respected. Sonny also sought peers with whom he could find solidarity in political action. In his case, an initial drive to fit in and accommodate to others who were interpreting him as "different" ing such students others holding ideals similar to his own. But, finding such students sent him far afield from peers in the School of 
Education to groups such as the Society of Hispanic Engineers.

Both of these young adults faced discrimination because of their language backgrounds and ethnic identities-experiences that are, for the most part, unfamiliar to their White peers. Both of their families had struggled for a toehold in the middle class and for identification as members of that group. Each of them also desired to help other young Latinos/as seeking a safe and welcoming place in American schools and the chance for school achievement and social mobility.

Interestingly, both Sonny and Patricia evidence strong ideas about social class hierarchies - who belongs in what categories-and how each of them is implicated in interpretations about who was to be viewed as educated, and who was, perhaps, not. Sonny said that his suburban secondary school peers thought he might be Mexican-someone whom they thought of as not speaking English well or as not having school content knowledge, a notion that he wished to disrupt; he was not Mexican. He saw himself as one of them, people who had grown up and lived in that suburb for a long time. Nor did Patricia see herself as allied with those of lower status birth; she was after all, a woman whose class background was both inherited and achieved. She seemed to be saying, "Why can't people see these things? I too am not Mexican-even if people call me this." When thought about as Mexican, both vehemently denied such affiliation and wished their classmates would see them otherwise. In assigning Sonny and Patricia an identity as Mexican, it seems that their classmates were saying something about people with brown skin, Spanish language skills, or Latino names in general: They are to be thought of as "lowstatus people."

Denying what others imagine as their identity does not allow Sonny or Patricia admission to an "insider" club of Whites, to whom their differences signal the category of other, or "Mexican." Accepting others' identity assignment means that they are caught in a dilemma, relegated to being an "other"; clearly, neither found this desirable. So, Patricia mounted arguments against such thinking and fought what were, at times, fruitless battles. And Sonny sought to minimize the differences that others saw, sometimes sublimating who he imagined he was in favor of acceptance. Both eventually sought solace with peers and/or teachers and students who reflected their Latino backgrounds. It also should be noted that both Sonny and Patricia have friends, respected colleagues, and/or mentors who self-identify as Mexican or Mexican American. Sonny and Patricia primarily seemed concerned with being called Mexican as a way of assigning a particular status marker to them. Research on transnationalism and race has helped us understand what we witnessed unfolding in Sonny's and Patricia's stories and concerns 
about being called Mexican. Ong (1996) theorized that notions about race, social class, and citizenship often converge as people think about who can be thought about as legitimate persons-those who have a right to live, work, be schooled, and access health care in a particular location. Hierarchies of persons' worth often are constructed as a means of determining which groups are seen as possessing requisite dimensions for belonging, or as people who "count," and whose concerns should be taken seriously in our country. Ong wrote,

Attaining success through self-reliant struggle, while not inherently limited to any cultural group, is a process of self-development that in Western democracies becomes inseparable from the process of "whitening." . . . . Because human capital, selfdiscipline, and consumer power are associated with whiteness, these attributes are important criteria of nonwhite citizenship in

Western democracies. (p. 739)

Ong explained that there is a racializing of the citizen that cannot be discounted in discussions of who people are and what geographic locations they come from. Thus, as Sonny and Patricia rankled at being called "Mexican," they implicitly were asserting that they and their families had to berned the privilege, as Ong aptly stated, "through self-reliant struggle" to be seen as worthy Americans-different from other people who often are viewed as being present in this country without documentation and perhaps as having little, unskilled, or no employment. Mexican, then, jected to "discriminatory modes of perceptionsly nonwhite" and are sub(p. 739). Ong further argued that "racial option, reception, and treatment" work of discriminatory laws and "racial oppositions are not merely the of people's maintenance of their outright racists but the everyday product norms against the socially deviant newcomers who disturb that sense of
comfort" (p. 740). Sonny and Patricia

Sonny and Patricia both were asserting that they were not "Mexican,"
the "deviant newcomers" ethnic heritage and were not in the imaginations; they were of a different ies that resided in the minds of category of what a "Mexican" embodwere asserting that they wisheds of their classmates. Sonny and Patricia citizenship rights in they wished to be seen as people who deserved full

Sonny's life story the eyes of those who interacted with them. ing dimensions of identity-ind Ong's (1996) work highlights, that differinteractional and language practices- come together in different
- comerial social class, culture, and 
degrees in different contexts. Sonny views himself, for example, as an insider in the suburbs before leaving for Guatemala. Upon his return, he envisions himself an outsider who acutely feels the gaze of others, locating him as "different" from them. In both the suburban setting and at State University, Sonny works hard to accommodate to others' sometimes "mind-numbing" behaviors and to acquire their tacit approval until he is able to find friends who are more like him in ethnicity, language background, or interests beginning in his sophomore year in college. Narrating his story in a coherent fashion requires that he sometimes see himself as on the inside and sometimes on the outside. It seems that these conflicting interpretations of self and location lead him to think about either returning to the suburb where he insists he belongs, or perhaps seeking to avoid issues of identity all together, dreaming of traveling the world with a class of students.

Patricia, on the other hand, seems to have an unwavering, well-established view of herself as an outsider, but one who deserves respect as what Ong (1996) termed a "citizen"-one who has earned the perquisites of this designation through her family's education, social status, and hard work. Patricia interprets classmates' and others' conversations about her family as placing them on the outside of what she sees as them having "earned" through their struggles. In the Midwest, her mother repeatedly is insulted for her language skills; in the South, she and her family's identity is questioned by both Black and White peers-regardless of their "mini mansion" and her father's occupation. And at State University, she finds herself asking "all the hard questions" of classmates, showing that she is smart and a critical thinker and having them ignore her queries. She seeks community and what she calls a "family" as part of her university life, and she creates this by founding her sorority. And, consistent with the stories of marginalization she narrates, Patricia says that she seeks a larger physical community of Latinos/as in Florida who also will serve as her metaphorical community-people she hopes will reflect her background and experiences and will recognize and be accepting of her as an educated Latina of a certain social class.

If Sonny and Patricia are to successfully teach all children, they need to consider how their desire to be viewed as someone who counts-a person to be respected, a person who belongs-also potentially marginalizes others. Both Sonny and Patricia would benefit by interrogating ways that they have internalized racialized notions about who constitutes a "lower status" person, how these ideas function, and who deserves to be seen as a citizen. 


\section{IMPLICATIONS FOR TEACHER EDUCATION}

What implications do Sonny's and Patricia's life stories have for teacher educators and teacher education? Our exploration of two teacher candidates' life histories suggests that teacher educators in universities with primarily White student bodies (and these do exist not only at State University but also in many parts of the United States) need to be aware of how students of color have been, can be, and are marginalized in their dormitories, classrooms, and general social experiences. We want teacher educators to model classroom practices that honor prospective teachers' prior knowledge, experiences, questions, and concerns. Often, it is not apparent to a teacher that the thinking and conversation of one, two, or a few students are silenced by the majority and that their questions either are not entertained or are dismissed by the larger group. We want teacher educators to seek out and make visible the questions and concerns mirroring those of students from diverse backgrounds and to bring these to the table of conversation. We want teacher educators to focus on "multicultural talk" about theory and practices that enhance the learning of all students-ensuring that those who have experienced being the "other" in school classrooms and on playgrounds do not continue these experiences in programs of teacher education.

For example, many middle-class White teacher candidates at State University have very particular assumptions about the relationship between their students' social status and their abilities and achievement in reading. These prospective teachers see low-socioeconomic-status families, often people of color, as lacking books, as failing to read to their children, and generally as responsible for their children coming to school "unprepared" for the challenges it offers. It takes a very strong prospective teacher, especially if she is a person of color, to stand against peers and question faulty assumptions about students and their families. ${ }^{3}$ When such questions are raised, students who dominate the discussion can easily dismiss those of the questioner, leaving her feeling more vulnerable and alone. This is a point at which a strong and concerned voice from the course teacher is imperative in challenging such flawed notions, and even more powerful when that voice evidences personal and research-based knowledge about the issue at hand.

In addition. these data analyses suggest that whom we seek to hire as teacher educators needs to change. The professoriate in teacher education is a predominantly White and monolingual (in English) one. Who teacher educators are does matter both to the university students we teach and to the students whom they in turn will educate. The course content that teacher educators see as important, the kinds of assignments 
ve give, whom we call on to lead groups and activities, and the discusions we promote in our classrooms all are related to our own identities, experiences, and concerns. We must see the concerns of all teacher candidates, especially those who could be marginalized in our classrooms, as our concerns also. This is much more likely if we share such experiences or backgrounds with our university students.

An example of how background experiences may influence teacher educators' decisions comes from Mary Louise's recent conversation with a Latina doctoral candidate, Lara Dominguez. She recounted a story about the experiences of some undergraduates in a support group that she leads for first-time college attenders of color, a few of whom she hopes will be teachers. Lara said that two of her undergraduate mentees were having a difficult time in a university math course. The students told Lara that the mathematics class, taught by Jack Smith (a White teaching assistant), had been going quite well in the initial days of the semester. The students told her that Smith seemed "all right"-he explained concepts well and was pleasant to all students. However, when many students in the class complained to the teaching assistant that they already knew the material in the initial book chapters, he agreed to skip the opening chapter or two so that they would not be bored. Lara said that what this teacher did not think about or recognize was that a few of the students of color in the class were not bored or familiar with the material; they sorely needed the explanations that they missed when he skipped over the material. Unfortunately, they were too embarrassed, amid their peers' cries of boredom, to admit their need for instruction on the material in question. Now, she said they were going to drop the course, leaving them both with fewer credits than they needed and with feelings of failure.

Lara said that she believed the teaching assistant's decision reflected a status of privilege-had Smith been reflecting on a personal background similar to that of the students, he might not have assumed that everyone in the class was well prepared in the initial concepts that grounded knowledge in the course. He might have tempered students' cries of boredom by talking about how the course was predicated on everyone having a good foundation for concepts to be taught later and that he assumed that there were holes in everyone's knowledge and understandings. Lara wondered, how could a more equitable ending have played out in this situation, one that ensured that the undergraduates she was mentoring received the education they needed? How could her students have received the instruction they needed without being seen as deficient (by the teaching assistant or by their classmates), as lacking the background for a beginning course in college mathematics? Lara's story illustrates in part that having more teacher educators and university teachers with 
diverse ethnic and social class backgrounds might attune teachers to the dilemmas that students in their classes may face. Lara's story also raises complex questions about how university teachers interpret the backgrounds and experiences of their students: How should we, as teachers, respond when some students say that they already know the material? Whom are we assuming the group speaking is speaking for? In what ways should we proceed when some students might know the material well, and others are newcomers to the information that we are presenting?

Further, Sonny's and Patricia's life histories suggest that we need to provide opportunities for ongoing interrogations and excavations of all teacher candidates' identities. If prospective teachers are to find community with those students whom they have viewed as "others," they must look first to their own cultural, class, and language backgrounds. Teacher candidates need to re-search their backgrounds for personal, familial, and community observations of and participation in prejudice and discrimination. Students of all backgrounds need to think about both how they have participated in, and have been the victims of, prejudice and discrimination. Of course, it is not only students of color who experience prejudice. For example, in our university in a large Midwestern state with many farms and small towns, students from these places are very familiar with the sneers of their city-born peers. Some of these students also have lived in rural poverty. They, too, know how prejudice works and yet can benefit from seeing how they often also are the recipients of the benefits of White privilege. Familiarity with the thinking, talk, and everyday lives of all those viewed as "others" may help prospective teachers see one another's viewpoints with differing lenses. These conversations likely should include a focus on issues concerned with ethnicity, language, social class, and geographic location. All prospective teachers, including teachers of color, need to question themselves and one another on such topics. These conversations need to be skillfully led, helping individuals to be critically reflective and to carefully consider one another's viewpoints and experiences.

Analyses of Sonny's and Patricia's experiences in teacher education also suggest that teacher education programs should make field experiences more arailable with Spanish-speaking and other language communities and should actively promote, encourage, and require teacher candidates' participation in the life of these classrooms. Sonny was able to negotiate three of five placements with a Spanish-speaking teacher and many Spanish-speaking children, but not all teacher candidates are so successful. Too many times, prospective teachers must request such multilingual placements themselves, and some teacher candidates may try to
avoid these. 
Although classroom-based field experiences are important, this exploratory analysis points to the need for teacher candidates to spend time in community settings with Latino/a peoples of differing social class and heritage backgrounds, and understand or experience what they honor in their lives and how they do so. Understanding the daily rhythms of families' lives-including their family interactional and language styles, religious practices, family celebrations, and so on-will help prospective teachers meet the needs of all children, including Latinos/as in school. Already, White teachers who are from middle-class backgrounds are at ease with those children who reflect their values and cultures; we must build more familiarity with all people outside prospective teachers' comfort zones and extant experiences.

In addition, our analyses imply that we need to capitalize on Latino/a prospective teachers' language skills and cultural knowledge. Both Sonny and Patricia had a great deal to offer in terms of their having lived internationally, their bilingualism, and their knowledge of varied cultural groups and their practices. These strengths and skills were largely untapped in the State University teacher education program. It also is clear from reviewing studies of other Latino/a prospective teachers (e.g. Tellez, 2000) that these strengths and skills also have been largely untapped or ignored in the experiences of other Latino/a teacher candidates. Another of our participants told of being required to prepare "a unit on Canada"-a vast nation with many peoples of different ethnic, language, and cultural backgrounds that he certainly could not cover in one unit nor have insider knowledge of-despite years of travel to and knowledge of Venezuela and Spain, his heritage nations. Both because
Canada is a large and diverse nation to cover in a "unit" and because the prospective teacher had a great deal of knowledge and experiences in other locales, this beginning teacher's students would have benefited if he were asked to create a different set of lessons, capitalizing on the knowledge of places and peoples with which he was very familiar. We believe that teacher education programs should build on, strengthen, and give explicit attention to what teacher candidates know and can do in terms of their own backgrounds and push them to acquire new knowledge and experiences.

The life histories of Sonny Garcia and Patricia Morales highlight particular dilemmas faced by teacher candidates who do not fit the predominant cultural model or generally accepted notion of who a U.S. teacher is-perhaps someone whose skin is brown, whose English may be accented, who fluently can speak two or more languages, and who may travel often between two or three nations to spend time with family and friends. Further research in a larger sample would shed light on the 
interpretations based on these data. These exploratory analyses suggest that we need to ask, How can we construct programs of teacher preparation that welcome prospective Latino/a teachers, providing safe and inviting places for them to consider their identities and their goals for teaching, and whom they want to teach and how they want to teach them? And how can we develop and capitalize on what Latino/a teacher candidates-indeed, teacher candidates from various language and cultural backgrounds-bring to our campuses and school classrooms?

\section{Acknowledgements}

The authors thank four anonymous reviewers and especially editor Lyn Corno for their helpful suggestions and critiques of the manuscript. We also are appreciative of comments on various drafts from James Paul Gee, Beth Graue, and Gloria Ladson-Billings of the University of Wisconsin-Madison, and Amy Suzanne Johnson of the University of South
Garolina.

\section{Notes}

1. The names of the university where this study took place, all other school sites, and locations, as well as the names of teacher candidates, practicing teachers, and all other persons are pseudonyms. Teacher candidates chose their own pseudonyms.

2. Valenzucla (1999) did not focus on studying teachers; rather, she researclied Mexican immigrant youth and second-generation Mexican American youth in a Texas high youth achicy relationships with their teachers, and the dimensions of schooling required for ond-generation youth, in particular, requrevant to this review. Valenzuela found that secidation of their cultural particular, required discussion of their personal concerns and valteachers. For these students knowledge before they would commit to learning with and from i.tion to school students, perceptions of teachers' indifference weakened students' affilopposition and lack of caring argued that "what looks to teachers and administrators like

3. For research of caring, feels to students like powerlessness and alienation" (p. 94).

they support children's reading focioconomic status families and families of color, and how compton-lilly (2003).

\section{References}

American Association of Colleges for Teacher Education. (1999). Teacher education pipeline 1: Schools, colleges, and departments of education enrollments by race, ethnicity, and gender.
Washington. DC: Author. Agruilar, J.. MacGilliway, L., \& Walker, N. T. (2000, April). Latina educators and dominant
scherel discomerses: The costs of success. Paper presented at the annual meeting of the American Educational Research Association, New Orleans, LA. 
Aguirre, A., Jr. (2005). The personal narrative as academic storytelling: A Chicano's search for presence and voice in academe. International Journal of Qualitative Studies in Education, $18,147-164$.

Capps, L, \& Ochs, E. (1995). Constructing panic: The discourse of agoraphobia. Cambridge, MA: Harvard University Press.

Clark, E. R., \& Flores, B. B. (2001). Who am I? The social construction of ethnic identity and self-perceptions in Latino pre-service teachers. Urban Review, 33, 69-88.

Cole, A., \& Knowles, G. (2001). Lives in context: The art of life history research. Walnut Creek, CA: Alta Mira Press.

Compton-Lilly, C. (2003). Reading families: The literate lives of urban children. New York: Teachers College Press.

Donato, R. (1997). The other struggle for equal schools: Mexican-Americans during the civil right ra. Albany: State University of New York Press.

Farber, B. A. (1991). Crisis in education: Stress and burnout in the American teacher. San Francisco: Jossey-Bass.

Flores, B. B., \& Clark, E. R. (2005). The centurion: Standards and high-stakes testing as gatekeepers for bilingual teacher candidates in the new century. In A. Valenzuela (Ed.), Leaving children behind: How "Texas-style" accountability fails Latino youth (pp. 225-248). Albany: State University of New York Press.

Galindo, R. (1996). Reframing the past in the present: Chicana teacher role identity as a bridging identity. Education and Urban Society, 29, 85-102.

Galindo, R., Aragon, M., \& Underhill, R. (1996). The competence to act: Chicana teacher role identity in life and career narratives. Urban Review, 28, 279-308.

Galindo, R., \& Olgun, M. (1996). Reclaiming bilingual educators' cultural resources: An autobiographical approach. Urban Education, 31(1), 29-56.

Garcia, E. E. (2001). Hispanic education in the United States: Raices y alas. Lanham, MD: Rowman and Littlefield.

Graue, M. E. (2005). Theorizing and describing preservice teachers' images of families and schooling. Teachers College Record, 107, 157-185.

Kauchak, D., \& Burbank, M. (2003). Voices in the classroom: Case studies of minority teacher candidates. Action in Teacher Education, 25(1), 63-75.

Linde, C. (1993). Life stories: The creation of coherence. New York: Oxford University Press.

Mishler, E. A. (1999). Storylines: Craftartists' narratives of identity. Cambridge, MA: Harvard University Press.

Monzo, L., \& Rueda, R. (2001). Professional roles, caring, and scaffolds: Latino teachers' and paraeducators' interactions with Latino students. American Journal of Education, 109, 438-471.

Olmedo, I. (2003). Accommodation and resistance: Latinas struggle for their children's education. Anthropology and Education, 34, 373-395.

Ong, A. (1996). Cultural citizenship as subject-making: Immigrants negotiate racial and cultural boundaries in the United States. Current Anthropology, 37, 737-762.

Reyes, P., Scribner, J. D., \& Scribner, A. P. (1999). (Eds.). Lessons from high-performing Hispanic schools: Creating learning communities. New: Teachers College Press.

$\mathrm{Su}, \mathrm{Z}$. (1997). Teaching as a profession and as a career: Minority candidates' perspectives. Teaching and Teacher Education, 13, 325-340.

Suarez-Orozco, M., \& Paez, M. M. (Eds.). (2002). Latinos: Remaking America. Berkeley: University of California Press.

Taylor, D., \& Dorsey-Gaines, C. (1988). Growing up literate. Portsmouth, NH: Heinemann. mez, K. (1999). Mexican-American preservice teachers and the intransigency of the elementary school curriculum. Teaching and Teacher Education, 15, 555-570. 
U.S. Census Bureau. (2000). Your gateway to Census 2000. Retrieved March 10, 2006, from http://www.census.gov/main/www/cen2000.html

U.S. Department of Commerce, Bureau of the Census. (2002). Educational attainment of the population 15 years and over, by age, sex, race, and Hispanic origin: March 2002. Washington,
DC: Author. U.S. Department of Education. (2001). The condition of education: 2001. Washington, DC:
Author.

Valdes, G. (1996). Con respeto: Bridging the distance between culturally-diverse families and schools. New York: Teachers College Press. Valencia, R. R. (2002). Chicano school failure and success: Past, present, and future. London:
Routledge/Falmer.

Valencia, R. R., Villareal, B. J., \& Salinas, M. F. (2002). Educational testing and Chicano students: Issues, consequences, and prospects for reform. In R. R. Valencia (Ed.), Chicano school failure and success: Past, present, and future (pp. 253-309). London:
Routledge/Falmer. State University of New York Press.

Villenas, S. (2001). Latina mothers and small-town racisms: Creating narratives of dignity and moral education in North Carolina. Anthropology and Education Quarterly, 32, 3-28.

Walker, N. T., MacGillivray, L., \& Aguilar, J. A. (2001). Negotiating higher education: Latina teachers' memories of striving for success. Ann Arbor, MI: Center for the Improvement of
Early Reading Achievement.

Yates, N. (1999, October 27). How California compares. Los Angeles Times, p. B2. Zimpher, N. (1989). The RATE project: A profile of teacher education students. Journal of
Teacher Education, 40, 27-30.

MARYLOUISE GOMEZ is professor of curriculum and instruction at the University of Wisconsin-Madison, where she studies the experiences and development of prospective teachers, and the teaching and learning of literacy. Recent publications include "Talking About Literacy: The Relationship Between a Teacher's Cultural Model of Teaching and "Tudents' Learning" in Journal of Early Childhood Literacy (2007), and "Textual Tactics of Identification" in Anthropology and Education Quarterly
(2004).

TERRI L. RODRIGUEZ is a former secondary school teacher and a doctoral candidate in literacy studies at the University of
Wisconsin-Madison. She directs the secondary teacher education pro-
gram for returning adult learno at gram for returning adult learners at Concordia University in Madison,
Wisconsin.

VONZELL AGOSTO is a former secondary school teacher and a doctoral candidate in multicultural education and teacher education at the University of Wisconsin-Madison. 